\title{
PERENCANAAN OBJEK WISATA ALAM DAN TANTANGAN DALAM PENYEDIAAN INFRASTRUKTUR TRANSPORTASI
}

\author{
Kaspan Eka Putra ${ }^{1}$, Zainuddin ${ }^{2}$ \\ ${ }^{1}$ Teknik Arsitektur Fakultas Teknik Universitas Pembangunan Panca Budi \\ ${ }^{2}$ Jurusan Arsitektur Fakultas Teknik Unsyiah \\ Jl. Gatot Subroto No.km, Simpang Tj., Kota Medan \\ *E-mail: ${ }^{1}$ kaspan12.kp@gmail.com
}

\begin{abstract}
Development of the tourist attractions are the leading sectors in encouraging the growth of development in the region. Each area that has a potential tourist attraction is planed and developed as a main destination that will be offered to tourists. This study analyzes the development planning of natural attractions and challenges in providing transport infrastructure. This study was conducted in Simalungun using primary data through observation of objects and explorative analyzes. The results showed there is a natural tourist attraction waterfall Tinggi Raja with huge potential, but constrained by the availability of transportation infrastructure that is very damaged. Simalungun government has not planned construction of the necessary infrastructure in the development of attractions.
\end{abstract}

Keywords: Attractions Planning and Transportation.

\section{PENDAHULUAN}

Meningkatnya destinasi dan investasi pariwisata menjadikan pariwisata sebagai faktor kunci dalam pendapatan ekspor, penciptaan lapangan kerja, pengembangan usaha dan infrastruktur serta perjalanan wisatawan mancanegara (wisman). Pariwisata telah mengalami ekspansi dan diversifikasi berkelanjutan, dan menjadi salah satu sektor ekonomi yang terbesar dan tercepat pertumbuhannya di dunia, UNWTO (2014).

Jumlah rata-rata kedatangan wisman pada Januari-November sebanyak $\quad 775.000$ kedatangan, namun untuk pertama kalinya dalam sejarah pariwisata Indonesia jumlah kedatangan pada Desember 2014 mencapai lebih dari 900.000 kedatangan, meningkat 5,97\% dari Desember 2013 yang mencapai 860.655 kedatangan. Sedangkan jumlah wisatawan nusantara pada tahun 2013, mencapai 248 juta perjalanan dengan pertumbuhan $1,1 \%$ dibandingkan dengan tahun sebelumnya. Jumlah ini membuat pengeluaran domestik sebesar Rp 176 triliun. Pada tahun 2013, indeks daya saing pariwisata menduduki peringkat ke-70 dari 140 negara dan peringkat 9 di Negara Asia berdasarkan jumlah pemasukan devisa negara yang mencapai US\$10,054 Milliar, meningkat $9,2 \%$ dari tahun sebelumnya yang mencapai US\$9,21 Milliar.

Jumlah wisman yang berkunjung di Sumatera Utara melalui 3 (tiga) pintu masuk pada bulan Oktober 2015 mencapai 16.430 kunjungan, mengalami penurunan sebesar 6,83 persen dibanding yang datang pada bulan September 2015 yang mencapai 17.635 kunjungan. Demikian pula, jika dibandingkan dengan bulan yang sama tahun 2014, jumlah wisman pada bulan Oktober 2015 mengalami penurunan sebesar 30,45 persen, yaitu dari 23.624 kunjungan turun menjadi 16.430 kunjungan pada bulan Oktober 2015. Wisman dari Negara Malaysia merupakan yang terbesar yaitu sebanyak 8.415 kunjungan atau 51,22 persen dari total wisman yang berkunjung ke Sumatera Utara, BPS (2015).

Formulasi Strategi dengan Konsep "GREAT" yaitu sebuah pendekatan pembangunan daerah pariwisata yang mengintegrasikan komponen; seperti infrastruktur, aksesibilitas, konektivitas, aktifitas, fasilitas, perhotelan, dan preferensi pasar (pintu masuk/pintu distribusi, pola pergerakan wisata, kesiapan dan kepastian bisnis dan manajemen pariwisata) untuk 
mengoptimalkan nilai ekonomi dan dampak positif untuk masyarakat, bisnis dan daerah.

Porter (2014) menyebutkan bahwa competitive advantage membutuhkan faktorfaktor pembangun seperti: Cost Advantages, keunggulan atas biaya yang harus dikeluarkan dalam penyediaan produk dan pelayanan wisata merupakan faktor penting dalam membangun keunggulan kompetitif destinasi pariwisata. Di dalamnya bergabung berbagai faktor yang mampu mengembangkan kinerja destinasi seperti perencanaan (desain); pengembangan produk wisata; pemasaran; pelayanan; serta harga. Dalam konteks pemerintahan, keunggulan biaya dapat pula dibantu dengan harmonisasi regulasi antara pemerintah pusat dan daerah yang terkait dengan insentif keuangan, penetapan tarif serta skema perpajakan atau retribusi. Differentiation membedakan destinasi dan produk pariwisata merupakan fokus dalam mengembangkan keunggulan komparatif kepariwisataan. Suatu destinasi pariwisata harus mampu menjadi berbeda dengan pesaingnya ketika menghasilkan aksesibilitas, atraksi dan amenitas yang unik dan berharga bagi wisatawan yang datang. Diferensiasi tidak melulu dilakukan dengan hanya menawarkan harga produk dan pelayanan yang lebih rendah. Infrastructures, kondisi prasarana dan sarana pendukung kepariwisataan yang terpelihara dan beroperasi dengan baik juga merupakan faktor penting pembangun keunggulan kompetitif suatu destinasi pariwisata. Artinya dengan infrastruktur yang baik akan mendukung peningkatan wisatawan datang ke wilayah wisata tersebut, misalnya infrastruktur jalan yang memadai dan dapat dicapai dengan mudah, infrastruktur penginapan dan lain sebagainya.

Pengembangan kawasan objek wisata merupakan sektor andalan dalam mendorong pertumbuhan pembangunan di daerah. Setiap daerah yang memiliki potensi objek wisata diarahkan untuk merencanakan dan mengembangkan sebagai destinasi andalan yang akan ditawarkan kepada wisatawan. Objek Wisata Alam Tinggi Raja sangat bagus, namun tingkat kunjungan wisatawan sangat rendah. Bagaimana dukungan sarana transportasi menuju objek wisata yang dibangun oleh Pemerintah Daerah.

Pengembangan wisata alam membutuhkan investasi yang relatif besar terutama menyangkut perencanaan, pelaksanaan pembangunan dan pengembangannya unsurunsur pokok yang harus mendapatkan perhatian adalah Objek dan Daya Tarik Wisata, Sarana Wisata, Prasarana Wisata, Masyarakat di Sekitar Objek Wisata. Semua unsur ini harus dikembangkan dengan baik guna menarik minat para wisatawan lokal maupun mancanegara.

Gunn (1994) menyatakan bahwa dalam pengembangan pariwisata harus melibatkan tiga sektor, yaitu Business Sector, Nonprofit Sector dan Governmental Sector, dan semakin baik pemahaman dan keterlibatan tiga sektor tersebut, maka pengembangan pariwisata akan semakin baik.

Perencanaan pengembangan pariwisata adalah serangkaian sistem tujuan dan pengaturan keseluruhan, berdasarkan daerah pariwisata, sejarah, situasi saat ini dan pasar faktor. Rencana pengembangan pariwisata oleh perencanaan ruang lingkup dan tingkat pemerintahan dibagi ke dalam:

1. Perencanaan pembangunan pariwisata nasional;

2. Perencanaan pengembangan pariwisata regional dan local; dan

3. Perencanaan pengembangan pariwisata.

Isu-isu yang menganggap penguatan partisipasi masyarakat melalui pengembangan pariwisata dan partisipasi lokal semakin penting dan diperdebatkan, sehingga membutuhkan penelitian lebih lanjut dan analisis (Gambar 1) (Simmons, 1994; Joppe, 1996; Pearce et al, 1996;. Ashley, 2000; Scheyvens, 2000; Macleod, 2004; Mitchell \& Muckosy, 2008; Simpson, 2008).

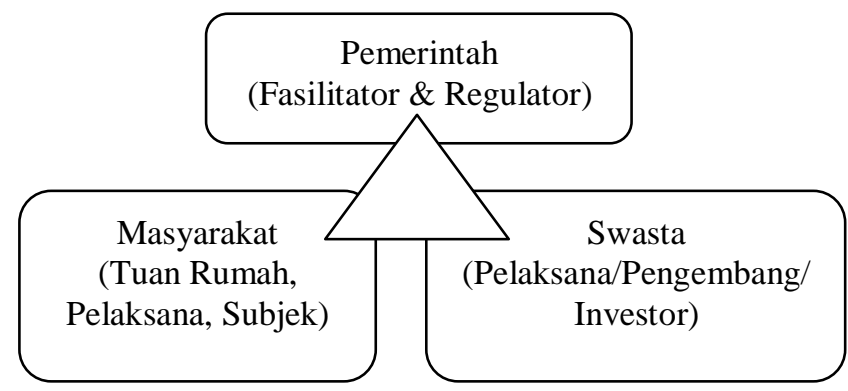

Gambar 1. Pemangku Kepentingan dalam Pengembangan Pariwisata

Sumber: Diadaptasi dari Wearing, 2001

Untuk meraup devisa bagi negara dari sektor pariwisata, tidak cukup hanya dengan mengandalkan keindahan alam dan keunikan budayanya saja. Pembenahan dan perbaikan 
infrastruktur memainkan peranan penting untuk mendukung keindahan alam, di samping keramahtamahan dan rasa kekeluargaan yang tidak bisa dilupakan. Perlunya komitmen bersama dari semua elemen baik dari pemerintah, swasta maupun masyarakat untuk menjadikan pariwisata di Sumatera Utara sebagai aset yang mempunyai potensi besar. Artinya pariwisata dianggap sebagai aset yang dapat memberikan manfaat yang banyak bagi semua pihak, bagi masyarakat pariwisata dapat memberikan kesempatan atau peluang untuk bekerja dan berusaha serta dapat meningkatkan pendapatan masyarakat, bagi pemerintah pariwisata dapat memberikan andil yang sangat besar bagi Pendapatan Asli Daerah (PAD), bagi swasta pariwisata merupakan peluang untuk mengembangkan usaha yang lebih besar lagi.

Keberhasilan pengembangan pariwisata ditentukan oleh beberapa faktor, yaitu tersedianya objek dan daya tarik wisata, adanya fasilitas aksesbilitas, yaitu sarana dan prasarana yang memungkinkan wisatawan mengunjungi suatu daerah atau kawasan wisata dan tersedianya fasilitas amenities yaitu sarana kepariwisataan yang dapat memberikan kenyamanan pelayanan kepada masyarakat.

Pengembangan infrastruktur dengan memperbesar aksesibilitas menuju dan dalam destinasi pariwisata melalui pembangunan serta perluasan jaringan jalan, bandara, pelabuhan laut, jaringan telekomunikasi, penyediaan listrik dan air bersih. Ketersediaan infrastruktur yang memadai akan meningkatkan daya saing serta daya tarik dalam penyediaan fasilitas kepariwisataan di suatu daerah tertentu.

\section{METODE PENELITIAN}

Berdasarkan permasalahan penelitian yang akan dijawab dalam penelitian yang dilaksanakan di Objek Wisata Alam Tinggi Raja Kabupaten Simalungan, penelitian ini menggunakan pendekatan eksploratif. Untuk mengumpulkan data dilakukan survei dan observasi terhadap objek dan melakukan perjalanan untuk medapatkan data tingkat pelayanan transportasi menuju objek yang diteliti. Data sekunder juga diperlukan dalam penelitian ini yaitu data hasil publikasi yang terkait dengan penelitian ini. Setelah data diperoleh maka data dianalisis untuk menjawab permasalahan penelitian.

\section{HASIL DAN PEMBAHASAN}

Dolok Tinggi Raja sudah ditemukan sekitar ratusan tahun lalu. Dolok Tinggi Raja ini terletak di daerah Desa Tinggi Raja Kecamatan Silau Kahean Kabupaten Simalungun Sumatra Utara. Tinggi Raja adalah tempat dimana terdapat mata air yang membentuk bukit kapur dari belerang. Menurut cerita masyarkat setempat kawasan Tinggi Raja berasal dari empat marga Damanik, Sipayung, Saragih dan Purba. Kampung ini dulu bernama Bauan. Sejarahnya, saat itu Raja Purba melakukan kenduri dan dalam kenduri tidak dibenarkan memakan hati kerbau yang menjadi pantangan dari raja. Namun anak raja mengambil hati kerbau tersebut dan melanggar peraturan dengan makan hati kerbau bersama masyarakat lainnya hingga terkena sumpah oleh Tinggi Raja. Sebagian masyarakat banyak yang mati dan anak raja mencoba melarikan diri. Meskipun sempat melarikan diri ke daerah Lintong Tapanuli namun kematian tidak dapat dielakkan oleh anak raja. Dirinya mati setelah datang air panas yang menghantam dirinya. Setelah muncul air panas tersebut terbentuklah Bukit Kapur yang sekarang menjadi fenomena alam.

Pada tahun 1928 gunung di Tinggi Raja meletus (Gambar 2) sehingga masyarakat Tinggi Raja menggungsi dan meninggalkan daerah ini dan beberapa lama Tinggi Raja tidak berpenghuni. Baru pada tahun 1986 daerah ini didatangi seorang Raja Purba dan pengikutnya untuk menghuni kawasan Tinggi Raja.

Sampai saat ini populasi masyarakat di Tinggi Raja terus bertambah seiring berkembangnya pembukaan lahan perkebunan di sekitar wilayah ini. Objek wisata ini mulai didatangi oleh pengunjung dari berbagai daerah.

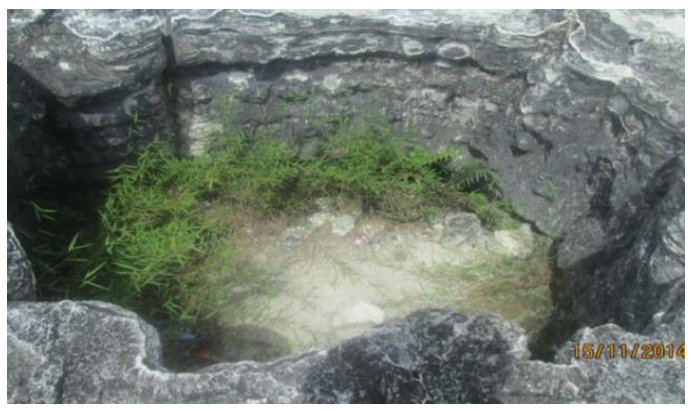

Gambar 2. Bekas Gunung Meletus

Secara ilmiah proses terjadinya kawah air panas Tinggi Raja ini diakibatkan oleh air yang meresap ke dalam kerak bumi kemudian dipanaskan oleh bebatuan yang bertemperatur tinggi yang kemudian menguap ke permukaan, 
dengan suhu yang panas, uap dapat mencairkan padatan mineral seperti kapur dan belerang. Kawasan ini telah dilindungi sejak tahun 1924 melalui keputusan bersama raja-raja Simalungun. Luas keseluruhan Cagar Alam ini adalah 167Ha. Keunikan yang khas dari kawasan ini adalah potensi sumber air panas yang berasal dari endapan-endapan kapur yang terbentuk dari proses panas bumi yang mengandung belerang sehingga membentuk teras-teras tanah kapur berbukit. Aliran air panas ini menyatu dengan air sungai sering dimanfaatkan untuk mandi karena airnya terasa hangat-hangat kukuh.

Kawah Biru Dolok Tinggi Raja ini memiliki bukit belerang putih seperti salju yang mengalirkan air panas menuju kawah besar di bawahnya membentuk kolam air panas berwarna biru yang sangat jernih. Lokasinya berada di tengah-tengah kawasan hutan lindung dengan pepohonan yang lebat dan diantara bukit kapur yang putih seperti salju dengan air panas yang memancarkan biru agak kehijauan.

Pada Gambar 3 dapat dilihat pemandangan objek pada kawah biru yang masih alami dikelilingi pepohanan yang sangat menarik bagi wistawan. Pada kawasan ini juga terdapat Bukit Kapur Tinggi Raja yang berwarna putih kehijau-hijauan dan di bagian bawah bukit kapur ini terdapat air sungai Bah Balakbak yang sangat sejuk dan dingin dengan pemandangan stalaktit (endapan kapur yang menggantung). Ketika pengunjung datang kesini, pengunjung dapat menikmati keindahan pemandangan kawah biru.

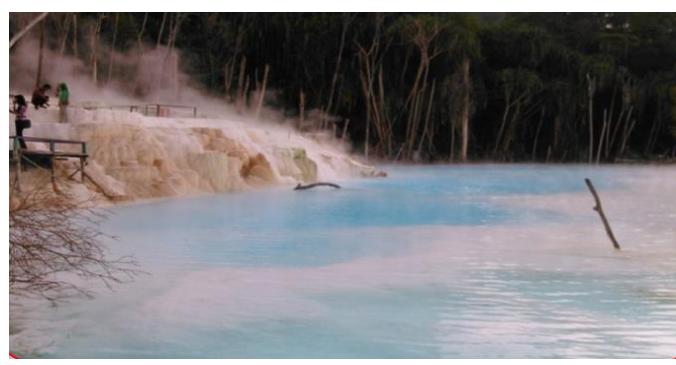

Gambar 3. Kawah Biru Dolok Tinggi Raja

Ada juga asap-asap yang keluar dari air kawah ini karena airnya panas sehingga mengluarkan uap-uap air. Sumber air panas ini juga memiliki potensi untuk menambah fasilitas kolam-kolam pemandian untuk para pengunjung yang datang agar dapat memanjakan dirinya untuk berendam dalam kolam tersebut (Gambar 4).

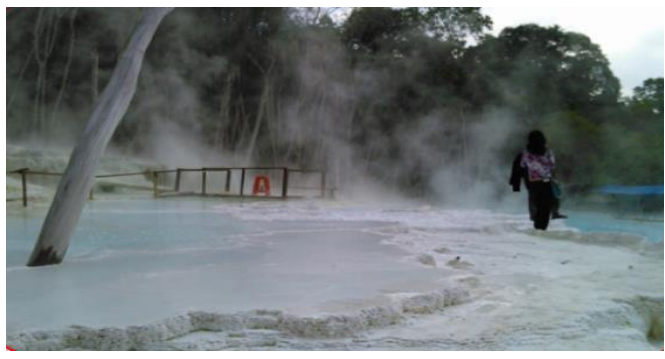

Gambar 4. Asap yang Keluar dari Air Kawah

Ketika memasuki kawaasan kawah putih, aktifitas yang dapat dilakukan para pengunjung dengan menyelusuri sungai yang jernih dan berada di tebing bertingkat dengan bebatuan butih dialiri air panas dan memantulkan cahaya berwarna-warni membentuk pemandangan sangat indah secara alami.

Tebing kawah putih mengalirkan air menuju sungai yang sangat jernih dan alami, sehingga menarik bagi wisatawan untuk mandi dan beredam dalam sungai dengan dua variasi suhu panas dan dingin yang dapat memanjakan pengunjung objek ini (Gambar 5).

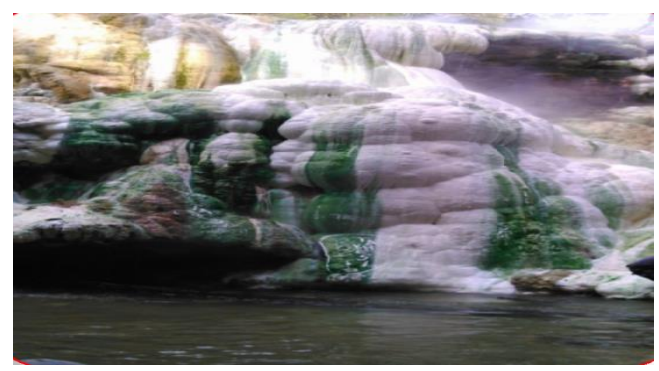

Gambar 5. Air Terjun Tinggi Raja

Cagar Alam Tinggi Raja merupakan suatu objek wisata yang masih dilindungi dan masih alami. Oleh sebab itu pengembangan Cagar Alam Tinggi Raja perlu diperhatikan. Cagar Alam Tinggi Raja ini juga mempunyai potensi yang sangat baik untuk dikembangkan karena memiliki keistimewaan berupa air panas yang bercampur belerang. Saat ini terdapat kendala aksesibilitas menuju objek masih sangat rendah.

Perjalan menuju objek wisata Tinggi Raja dari kota Medan menuju Lubuk Pakam dan diteruskan perjalanan menuju Kecamatan Silau Kahean Kabupaten Simalungun. Perjalanan darat dengan menggunakan mobil pribadi ditempuh dengan perjalanan selama 3 jam. Jarak perjalanan sejauh $95 \mathrm{~km}$ dari Kota Medan. Kondisi jalan sejauh $25 \mathrm{Km}$ sangat rusak sehingga kecepatan kenderaan maksimal 
$15 \mathrm{~km} / \mathrm{jam}$. Menggunakan angkutan umum dari Kota Medan bisa dilakukan dengan menggunakan Bus Sumber Jaya dan Angkot Netis. Tetapi bus dan angkot tersebut hanya bisa sampai di Pos Polosi Desa Tanutan.

Jalan menuju objek wisata tingkat pelayanan jalan sangat rendah, permukaan jalan masih berbatu, bergelombang, becek dan sempit. Pada Gambar 6 dapat dilihat ruas jalan yang sangat sempit untuk dilalui kenderaan bermotor. Panjang jalan dengan kondisi ini sepanjang $10 \mathrm{~km}$. Hal ini merupakan kendala dalam pengembangan Objek Wisata Tinggi Raja. Tingkat kunjungan pada objek ini masih sangat rendah yaitu 150 pengunjung perhari pada hari libur.

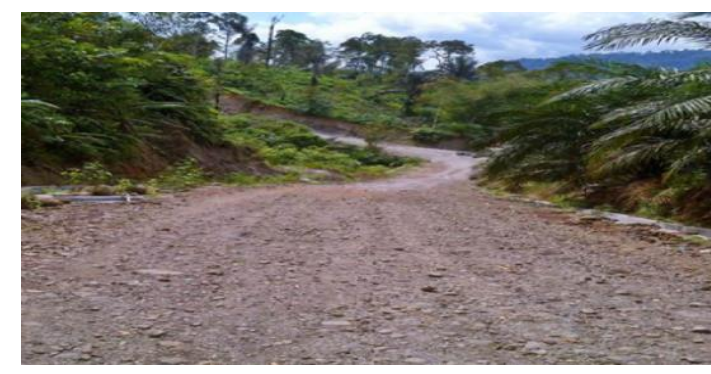

Gambar 6. Kondisi Jalan Menuju Objek Wisata Tinggi Raja

\section{KESIMPULAN}

Objek Wisata Alam Air Terjun Tinggi Raja yang sangat potensial untuk dikembangkan, namun terkendala ketersedian infrastruktur transpotasi menuju obejek yang sangat rusak. Pemerintah Kabupaten Simalungun belum merencanakan pembangunan infrastruktur yang dibutuhkan dalam pengembangan objek wisata. Pembenahan dan perbaikan infrastruktur memainkan peranan penting untuk mendukung keindahan alam, disamping keramahtamahan dan rasa kekeluargaan yang tidak bisa dilupakan. Perlunya komitmen bersama dari semua elemen baik dari pemerintah, swasta maupun masyarakat untuk menjadikan pariwisata di Sumatera Utara sebagai aset yang mempunyai potensi besar

\section{Daftar Pustaka}

Ashley, C. (2000). The impacts of tourism on rural livelihoods: Namibia"s experience. Working Paper 128,
Overseas Development Institute (ODI). London, England.

Badan Pusat Statistik Provinsi Sumatera Utara No.74/12/12/Thn XVIII, 01 Desember 2015.

Gunn, C.A 1994. Tourism Planning. Taylor and Francis. Wasington.

Joppe, M. (1996). Sustainable community tourism development revisited. Tourism Management. Vol. 17, No. 7, pp. 475479, 1996.

Macleod, D.V.L. (2004). Tourism, Globalisation and Cultural Change: An island community perspective. Clevedon, Buffalo \& Toronto: Channel View Publications.

Mitchell, J. \& Muckosy, P. (2008). A misguided quest: Community-based tourism in Latin America. Article Opinion 102, Overseas Development Institute (ODI). London, England.

Pearce, P.L., Moscardo, G. \& Ross, G.F. (1996). Tourism Community Relationships. Oxford: Pergamon.

Porter, Michael E. (2004), Competitive Advantage: Creating and Sustaining Superior Performance, with a new introduction, copyright 1985, Free Press Publishing, New York.

Scheyvens, R. (2002). Tourism for development: empowering communities. Essex, London: Pearson Prentice Hall.

Simmons, D.G. (1994). Community participation in tourism planning. Tourism Management. Vol. 15, No. 2, pp. 98-108, 1994.

Simpson, M. (2008). Progress in tourism management: Community Benefit Tourism Initiatives: A conceptual oxymoron? Tourism Management. Vol. 29, No. 1, pp. 1-18, 2008.

Wearing, S.L. and Donald, Mc. 2001. "The Development of Community Based Tourism: Re-Thinking The Relationsgip 
between Tour Operators and Development Agents as intermediaries in rural and isolated area Communities." Journal of Sustainable Tourism.

UNWTO Tourism Highlights, 2014, UNWTO World Tourism Barometer, Jan. 2015 WTTC, Jan. 2015 dalam Pembangunan Infrastruktur Untuk Peningkatan Daya Saing Pariwisata oleh Dr. Ir. Arief Yahya, M.Sc, Menteri Pariwisata Republik Indonesia pada 29 April 2015, Jakarta. 